\title{
Performance Analysis of HIGHER ALCOHOL/GASOLINE BLENDS as a fuel in 4-stroke SI engine.
}

\author{
PriyankaA.Taksande, Dr.S.C.Kongre \\ SSPACE Wardha , Reg.No.PhD(cell) RRC/Guide/2209/B/1109
}

\section{Introduction:-}

An experimental investigation of combustion characteristics of higheralcohols/gasoline (UTG 96) blends is presented. Lower alcohols (methanol and ethanol)have been used in the past as fuel extenders by mixing them with gasoline, but relativelylittle work has been reported on higher alcohols (propanol, butanol, and pentanol).

Comparisons of knock limits, indicated mean effective pressure (IMEP),emissions, and fuel characteristics between higher alcohol/gasoline blends and neatgasoline were made to determine the advantages and disadvantages of blending alcoholwith gasoline. All tests were conducted on a single-cylinder Waukesha Cooperative FuelResearch (CFR) engine operating at steady state conditions and stoichiometric air-to-fuelratio.

The alcohol component of the blends consisted of methanol, ethanol, propanol,butanol and pentanol.Apparatuses used in the present study were a single cylinder spark ignition engine, a hydraulic dynamometer and an exhaust analyzer. The variables that were continuously measured include engine rotational speed (rpm), $\mathrm{CO}, \mathrm{CO} 2, \mathrm{HC}$ and $\mathrm{NO}$ emissions. During a variable load tests, the results indicate that $\mathrm{CO}$ and $\mathrm{HC}$ levels in the engine exhaust are reduced with the operation on alcohol gasolineblends. NO emissions with alcohol gasoline blends are higher than with gasoline.

\section{Literature Review:-}

Literature review is an assignment of previous task done by some authors or collection of information or data from research papers published in journals. It is a way through which we can find new ideas, concept. Though there are lot of literatures published before on the same task; only two papers of them are taken into consideration from which idea of the project is taken and work is in progress for some other literatures.

ETHANOL:- Mustafa Koç, et. al. investigated experimentally, the effects of unleaded gasoline(E0) and unleaded gasoline-ethanol blends (E50 and E85) on engine performance andpollutant emissions in a single cylinder four-stroke spark-ignition engine at twocompression ratios (10:1 and 11:1). The engine speed was changed from 1500 to 5000rpm at wide open throttle (WOT). The results of the engine test showed that ethanoladdition to unleaded gasoline increase the engine torque, power and fuel consumption andreduce carbon monoxide (CO), nitrogen oxides (NOx) and hydrocarbon (HC) emissions.It was also found that ethanol-gasoline blends allow increasing compression ratio (CR)without knock occurrence.[1-3,11-13]

METHANOL:- K Venkateswarlu, M Ramesh, K Veladritested the effect of methanol-gasolineblends. Their work described the improved engine efficiency with higher compressionratios by using methanol-gasoline blends (mixing-methanol in small proportions withgasoline) as methanol had high anti-knock characteristics. Existing engines were notgenerally suitable to operate on higher contents of methanol, as the engine needs majormodifications. The present work considered methanol blended fuels M-10, M-20 and M-30 (number denotes the percentage of methanol in gasoline) as alternative fuel for fourstroke variable compression ratio spark ignition (S I) engine. Experimental resultsdemonstrated that an increase of $48 \%$ in brake thermal efficiency had been observed

compared to gasoline operation. An increase of $8 \%$ in volumetric efficiency was foundand a reduction of $24 \%$ in BSFC was observed.[4,11-13]

BUTANOL:- Alasfour,F.N.,explained that,Butanol is a potential alternative to ethanol and offers many benefits including a much higher heating value and lower latent heat of vaporization. It also has a higher cetane number than ethanol and improved miscibility in diesel fuel. Additionally, butanol is less corrosive and less prone to water absorption than ethanol, which allows it to be transported using the existing fuel supply pipelines. However, while some previous research on the emissions of butanol-gasoline blends is available, little research exists on the emissions of neat butanol.

This thesis focuses on two areas of study. The first area relates to on the comparison of UHC, NOx, and CO emissions of several butanol-gasoline and ethanol-gasoline blended fuels during combustion in an SI engine. The objective was to compare the emissions of butanol combustion to the ones of ethanol and gasoline. The second part of the study relates to the use of electrostatically assisted injection as a means of reducing the UHC emissions of butanol by decreasing the fuel droplet size using a charge electrode and extraction ring designed 
for a port fuel injector. Emissions measurements taken with and without a charge applied to the injector were used to determine the effect of applying a voltage to the fuel spray on engine emissions.

It was established that the UHC emissions of neat butanol were approximately double the UHC emissions of gasoline and were appreciably higher than ethanol. $\mathrm{CO}$ emissions decreased and NOx emissions increased as the amount of butanol in gasoline was increased. Additionally, the $\mathrm{CO}$ emissions of butanol were lower than ethanol while it was not clear whether butanol had increased or decreased NOx emissions. It was also established that addition of $25 \%$ ethanol to butanol resulted in UHC emissions that were approximately $33 \%$ higher than those of neat butanol despite ethanol producing approximately $33 \%$ less UHC emissions than butanol. The results of the electrostatically assisted injection tests showed that, at certain engine operating conditions, application of $2000 \mathrm{~V}$ to the fuel spray resulted in a $10 \%$ increase in peak cylinder pressure, $4 \%$ reduction in UHC emissions, a $13.5 \%$ increase in NOx emissions, and a $13.5 \%$ reduction in CO emissions, which is consistent with the hypothesis that the voltage increased fuel atomization. However, tests at lower engine loads showed results contradictory to those at the higher engine load which suggested that the fuel droplet size may vary depending on engine operating conditions. [5,6,11-13]

PROPANOL:-Tapan.N.A., explained that,Direct alcohol fuel cells have been attracting enormous research interest as power sources for vehicles and portable electronic devices because alcohols are readily available, their storage and transport can be easily handled with the existing fuel infrastructure, and they commonly have high mass-specific and volumetric energy densities. Methanol is the most studied fuel for direct alcohol fuel cells because methanol is readily available, it is structurally simple, and has a promising electrochemical activity. However, several research groups have also reported the use of 2-propanol as a promising fuel. The potential advantages of utilizing 2-propanol as fuel are many such as it is relatively less toxic compared to other alcohols, at low potentials it is less prone to anode poisoning, and it has better resistance to crossover and cathode poisoning. The performance of the fuel cell for a particular catalyst system is related to the cell conditions such as 2-propanol concentration, anode and cathode fuel flow rates, cell temperature and oxidant back pressure. This study was designed to study the effect of the different cell operation conditions at three different levels and the interactions between these components by response surface methodology (RSM). We observed that the power density of the cell increased with increase in molar concentration of 2-propanol and cell operation temperature, the optimized conditions for the highest power density of $45 \mathrm{~mW} / \mathrm{cm} 2$ by the RSM was found to be 1.5 M 2-propanol concentration, $80 \mathrm{oC}$ cell temperature, $9.22 \mathrm{ml} / \mathrm{min}$ 2-propanol flow rate, 596 $\mathrm{ml} / \mathrm{min}$ oxygen flow rate and no back pressure for the oxidant, this is from amongst one of the best results reported in literature for direct 2-propanol fuel cell performance.[7-10,11-13]

\section{OBJECTIVES}

The purpose of this research is to investigate the performance characterstics and exhaust gas characterstics of HIGHER ALCOHOL/GASOLINE BLENDS on 4-stroke SI engine.

\section{PLAN OF WORK:-}

1.Literature Review[08/2013 to12/2013]

2.Experimental set up[01/2014]

3.Experimentation[02/2014 to $04 / 2014]$

\section{References:-}

[1]. MustafaKoc,et.al. "The effect of unleaded gasoline and unleaded gasoline-Ethanol Blends on engine performance and pollutant emissions in 1-cylinder 4-stroke SI engine."

[2]. Al-Hasan, M., 2002. Effect of ethanol-unleaded gasoline blends on engine performance and exhaust emission. Energy Conversion and Management [44], 1547-1561.

[3]. Bayraktar, H., 2005. Experimental and theoretical investigation of using gasoline-ethanol blends in spark-ignition engines. Renewable Energy [30] 1733-1747.

[4]. KVenkateswarlu,MRamesh,KVeladri, "The effect of Methanol-gasoline Blends."

[5]. Alasfour, F.N., "Butanol - A single cylinder engine study: Engine performance," International Journal of Energy Research. 21(1): 21-30, 1997.

[6]. Alasfour, F. N., "Butanol - A Single-Cylinder Engine Study: Availability Analysis," Applied Thermal Engineering. 17(6): 537-549, 1997.

[7]. P. Chaurasia, Y. Ando and T. Tanaka, Journal of Energy Conversion and Management, 44 (2003) 611

[8]. J.T. Wang, S. Wasmus and R.F. Savinell, J. Electrochem. Soc., 142 (1995) 4218

[9]. Y. Ando, T. Tanaka, T. Doi and T. Takashima, Journal of Energy Conversion and Management, 42(15-17) (2001) 1807

[10]. Tapan, N.A.; K"ok, A. Chem. Eng. Commun. 2009, 196, 131-147

[11]. Gautam, M. e D. W. Martin II, D. Carder, 2000. Emissions characteristics of higher alcohol/gasolineblends. Proceedings of the Institution of Mechanical Engineers, Part A: Journal of Power andEnergy.

[12]. Martin II, Daniel W., "Combustion and Emissions Characteristics of Higher Alcohol/Gasoline Blends," Masters Thesis, West Virginia University, Department of Mechanical and Aerospace Engineering, 1997.

[13]. Brinkman, N. D., Galloupoulous, N. E., and Jackson, M. W., "Exhaust Emissions, Fuel Economy, and Driveability of Vehicles Fueled with Alcohol-Gasoline Blends," SAE. 